\title{
IRAD, A Major Player in Communication and Agricultural Development: For the Development of Cassava Producers in the City of Santchou (West Cameroon)
}

Noukio Germaine Bienvenue

Researcher in Social Sciences, National Center for Education, Yaoundé Cameroon

DOI: $10.36347 /$ sjahss.2020.v08i05.004

| Received: 09.05.2020 | Accepted: 16.05.2020 | Published: 19.05.2020

*Corresponding author: Noukio Germaine Bienvenue

\section{Abstract}

Original Research Article

Cameroonian youth, more and more turned towards self-employment, especially in the agro-pastoral world has a lot to gain from the culture of cassava which is a sector that holds many opportunities and whose products are high demanded on the international market. The Agricultural Research Institute for Development, the secular arm of the State through its sovereign missions of training and supporting producers, aims for their development and independence.

Keywords: IRAD, producer, cassava agriculture, development.

Copyright @ 2020: This is an open-access article distributed under the terms of the Creative Commons Attribution license which permits unrestricted use, distribution, and reproduction in any medium for non-commercial use (NonCommercial, or CC-BY-NC) provided the original author and source are credited.

\section{INTRODUCTION}

One of the fundamental missions of the Institute of Agronomic Research for Development is the communication of the latest results in terms of Research and especially the development of producers in several agricultural sectors. Given the poverty that threatens certain countries including Cameroon, the objective of this study will be to know how IRAD (Institute for Agricultural Research for Development) can facilitate the transmission of knowledge to the producers thanks to its technicians and to its researchers from different sub-directorates of its supervisory ministry (MINRESI) Ministry of Scientific Research and Innovation.

We will rely on the actions carried out by the agricultural extension section through its technicians in the field and the proved expertise of researchers in education sciences to explain how communication and development in the agricultural sector operates. We will take the example of cassava producers in the city of Santchou who, thanks to the collaboration of technicians / researchers, have succeeded in developing and implementing cultivation in other producers by means of vicarious learning.

\section{HISTORICAL BACKGROUND}

Agricultural development is a term, that can be used as well for design government agricultural policy applied to farms agricultural through institutions; that the technical and economic supervision of farmers; or the processes of transformation of agriculture and rural societies Fraslin [1].

Philippe Lacombe [2] speaks of development as a "contradictory process of alliances and conflicts between social groups involved in the society we are studying". Definition which is closed to that elaborated by Fraslin from Touraine's reflections on the social movement: development is known there as "a social movement, that is to say not only as the effect of the structures of supervision but also as that of the action of all the agents involved in this process " Fraslin.

The term agricultural development appeared in Cameroon over 60 years and has replaced that of agricultural vulgarization. This transition from one term to another took place following a series of transformations after the Second World War in the way of conceiving the dissemination of scientific knowledge in agriculture.

In the years 1935 the diffusion is in charge of the State and the role of popularizers consists in reaching the mass of the farmers by using simple but proved recipes. However, during this same period, the first Societies of Cameroonian Studies (SECAM) appeared, an organization whose purpose was to study all questions relating to the human sciences, geology, oceanography, flora and fauna, both terrestrial and 
marine, and, in general, all that relates to the peculiarities of the country.

The members of these companies are no longer satisfied with the simple recipes disseminated by the popularizers. "Popularization is no longer" top-down "but" bottom-up "popularization: farmers first raise questions and only then turn to popularizers" [3].

SECAM's work gave rise to the publication of the first Cameroonian scientific journal. Long before the creation of SECAM, German colonization had also created, from 1889, a few trial gardens in Edéa, Akonolinga and Limbé . Research on the rural world was also carried out at that time by individuals attached to scientific institutions (universities or metropolitan research centers) or others (church, army, etc.)

It was in the aftermath of the War of 19141918 that research began to take off with the creation, by the Agriculture Services of the High Commission of the Republic of Cameroon.

Many experimental stations are created: in Dschang in 1925 (arabica and cinchona coffee), in Ngaoundéré in 1930 (animal production), in Bambui in 1933 (food crops ), in Ebolowa in 1938 (robusta coffee and food crops), in $\mathrm{N}$ ' kongsamba (soils) and in Djarengol -Maroua (groundnut and animal traction).

There is no real coordination to follow a real policy in terms of guidance, and on the other hand these groups, although formally open to all farmers, concern only a minority of them. However, at the same time, the supervision in the performance of commercial, financial, technical and cultural functions is more and more advanced and makes the farms more and more dependent.

The establishment of agronomic research institutes results from the evolution of practices and controversies which pass from the initial stage of the test gardens, to that more elaborate of experimental stations, to finally reach the final institutional stage of research institutes. For Mina Kleiche, this three-stage periodization corresponds to "three key moments in agricultural experimentation and in the training of managers in the colonies; the transition from colonial agriculture to colonial agronomy in the 1920s; the emergence of tropical agronomy on the eve of the Second World War; its full development after 1954 ". During the "gardens" and "stations" phases, activities were limited to the collection of more or less elaborate information, which was then transferred to mainland France for processing for scientific purposes.
Test gardens before the First World War, experimental stations during the interwar period, and finally agricultural research institutes after the War of 1939-1945. This was the genesis of the emergence of the first research institutions in Cameroon, as in most of the countries of French-speaking West Africa (exAOF).

At independence, the Cameroonian state has an appreciable research infrastructure, and shows a particular interest in scientific and technical research, which is directly attached to the federal authorities, a measure which, at the time, testified of its importance for the authorities. The operating costs of the institutes were borned by the Cameroonian authorities, but the salaries of the researchers, who were mostly French, were provided by the former colonial power. The fact that research is, in part, supported by France, will allow the emerging Cameroonian state to initially concentrate its resources on higher education and training.

Human problems then enter into reflection and follow on from the technical aspects. It also appears essential to extend this popularization to non-staff of research institutes. The tendency is then to return to the traditional methods of mass dissemination of the popularizers of the $1950 \mathrm{~s}$ while trying to overcome them by a more global reflection on production, Faye [4].

\section{MATERIAL AND METHOD}

At the Agricultural Research Institute for Development, researchers and technicians join forces through training and information seminars and agricultural campaigns to get the message out to producers.

Each start of the agricultural campaign is preceded by great awareness through radio announcements and also through the representatives of producers brought together in the form of GICs (Group of Joint Initiatives).

This approach used by IRAD technicians and researchers is inspired by social marketing. Marketing which then has the double specificity of promoting the ideas of the institutions of the campaign while seeking to do this to meet the needs of the social groups for which these campaigns are intended, Dockes [5]. It is this double specificity that we find, expressed in other words, in the definition of marketing work given by Boullier [6]. This work is seen as a way to "get to know society in order to bend technical innovation (at the time of its conception) or, later, find the best passage in society for a given object, even if it means forcing this passage with advertising and almost supportive campaigns ". 


\section{ANAL YSIS}

Cassava is one of the most consumed foods in sub-Saharan Africa and particularly in Santchou, one of the cities of Cameroon renowned for production and because of its variety of processing and its easy cultivation on fertile soils as on poor fertility. Cassava is eaten from the leaves to the root, which gives cassava a great potential to contribute to food sufficiency in the Western region or even of the country. From an economic point of view, cassava producers have a large possibility of earning additional income because of the multiple products derived from this tuber.

Our objective in this section is to know how the technicians of the IRAD and the researchers in social sciences go about it in the sensitization of the producers in agricultural extension in the city of Santchou. What means do they have to be accepted and understood by producers?

We noted during our study that at the start of the agricultural campaign, the technicians and researchers summon the managers of the producers for an interview on the merits of growing cassava or whatever they would like to do; First, they make a general communication on the cultivation of cassava, explaining to them that Production involves working the soil, choosing and preparing seeds and planting. Second, cassava cultivation techniques includes: isolation, spacing, the use of micro-cuttings, purification, fertilization, etc. These practices allow the multiplication of healthy plants, free from diseases. After this overview, the technicians and researchers begin the basic communication which consists of:

- Perpetuate the plant material for a possible variety creation meeting their own needs,

- Maintaining the varieties of cassava present in their agro-ecological zone,

- Matching these varieties with those that best suit their growing area,

- Ensuring the conservation and continuing availability of genetic resources to improve the quality of cassava.

- Process the cassava obtained into different marketable products and

- Develop thanks to this production.

\section{The dominant authority of agricultural researchers and technicians}

In the Research Institutes and the Ministry in charge of agriculture, we have observed that the farmers who are the essential links in production are reduced to simple performers. Researchers are considered to be the all-powerful because they are the ones who produce the knowledge, the technicians who are permanently in the field are responsible for dissemination and the farmers, for their part, apply any order coming from the top.
Although being simple implementers, the farmers do not have the right to promote a first-rate idea without however referring to its supervision which is the researcher or the technician according to the order.

\section{NICT in Agriculture}

Thanks to New Information and Communication Technologies (NTIC), and above all to a wide range of methods and tools and especially via local media, IRAD experts communicate with producers so that they do facing social, economic and above all environmental challenges.

The priority objectives of researchers and technicians in communication matters aim at the development of producers, the dissemination of relevant information and above all social dialogue between them. These researchers give technical advice to development projects and programs by placing local media and ICTs at the heart of GICs (Grouping of Joint Initiatives).

These communication initiatives are very effective in improving learning opportunities, as well as technical advice in rural communication. In addition, learning and study opportunities are encouraged with other Research Institutes and Universities on rural communication for better dissemination of information in the agricultural field.

\section{DISCUSSIONS}

Cassava production does not require a diploma. On the other hand, it is necessary to obtain information from IRADs or other farmers who have learned this crop through training in the different methods of growing cassava and maintaining the plantation. The seeds (cuttings) are the cassava stalks. They can be obtained from agricultural research institutes, or failing this, produce the cuttings yourself. Some online farming sites provide sufficient information on this crop.

As for the transformation of cassava into derived products, it requires additional learning specific to the product that one wishes to market.

Cassava's clientele is varied. The harvested cassava roots are sold in local markets for a clientele generally made up of households. The roots can be transformed into semolina, starch, or flour. Starch from the roots is used in food products, plywood, paper and textiles. It is also used as a raw material for the manufacture of sweeteners, fructose, alcohol and ethanol fuel. The leaves are nutritious vegetables for households, and the skins can be processed into food for livestock, buffaloes, pigs, and chickens.

Additional income can be earned through processing into different food or industrial products. The main products from the tubers are: 
At the domestic level: foufou (dried cassava powder) very widespread in the country it is sold and consumed in almost all households.

The waterfufu (fresh cassava): is the more consumed and the main food produced in the santchou area. This product is sold throughout the Littoral, West region and also in other countries of the sub-region like Equatorial Guinea and Gabon.

The gari (tapioca), product derived from the culture of the cassava, it is consumed and marketed inside and outside the country. The producers find their account by practicing the small trade of these derived products.

The mitumba (grated cassava added with palm oil), more sold in the center and Littoral regions, it is one of the traditional dishes of these two regions.

The cassava fritters, cassava dumplings: these are very common foods that are marketed in schools in Cameroon. Very appreciated for their taste, the students love to eat them with beans.

Cassava sticks: in Cameroon and elsewhere, is one of the most consumed foods because it is accompanied by several other foods such as: fish, vegetables, ndolé, fried eggs, roasted peanuts, koki and others.

At the industrial level, we have:

- Starch: extra fine cassava powder used in industries and dry cleaning to improve the quality of the garment.

- The flour of cassava: it is used in making bread, pasta and others.

- The granulated cassava, glue, etc.

\section{The different virtues of cassava}

According to the results of research given by IRAD, Cassava contains several nutritional virtues. Rich in starch, carbohydrate and gluten, its root, although energetic, is poor in lipid, vitamin, mineral salts and protein. This protein deficiency makes him a food that should be accompanied in meals for a balanced diet. These traditional methods of preparation (fermentation) reduce its nutritional value.

Medicinally, the consumption of cassava roots is a solution for excess diarrhea, stomach aches and colon irritations. Because it is low in fat, the consumption of cassava tubers is recommended for people wishing to follow a diet low in fat.

Cassava leaves, like tubers, have many nutritional values, which is why their consumption is just as recommended by nutritionists. Rich in protein, they are an excellent dietary supplement when accompanied by roots or tubers.
In Cameroon, the populations make their dishes with young unripe leaves because they are rich in vitamin A important for growth and eyesight and in vitamin C. They are also good diets which help to lower the salt level in the body. The dried and powdered leaves are also an important healing agent for burns. The greenish juice from the crushed cassava leaves is effective in relieving people suffering from fever. Accompanied by condensed milk, this juice is prescribed for cases of anemia. In the opinion of doctors, people regularly consuming cassava leaves hardly contact malaria.

\section{Cassava: a solution for food self-sufficiency}

Robust and perennial, cassava is a tuber that can be eaten from the leaves to the root. Of the Euphorbiaceae family, its culture is generally done from 12 to 20 months, which makes possible a continuous marketing. It presents several varieties which differ in their morphological aspects. If it is easily cultivable in tropical regions, cassava therefore is the ideal food during dry seasons and periods of famine. It is therefore an essential solution to achieve the food self-sufficiency to which several African countries aspire.

Given the diversity of cassava products and its importance in food in Cameroon, we can say that the producer has enough to do as an activity by practicing cassava cultivation. We urge the sectoral ministries concerned here to be more careful in the area. More precisely the Ministry of Scientific Research and Development (MINRESI) which, in its role of head must provide researchers with substantial resources for the implementation of the objectives assigned by the said ministry. We also call on the Ministry in charge of Agriculture to support producers by granting them agricultural inputs to boost production in order to transform products into derivatives; this in order to provide for their own needs and to fight against poverty.

\section{CONCLUSION}

Cassava cultivation has great potential for productivity, which can guarantee high financial profitability. However, it struggles in Cameroon to meet the consumption needs of populations and the demand of industrialists. To benefit from this manna, Cameroonian farmers still face a large number of difficulties related to the quality of the fertilizers they use, the use of rudimentary working tools (hoes, machete, etc.), the lack of mechanization and financing when large projects arise. Added to this is the lack of training in modern farming practices and techniques that should make available the volumes desired by internal and external markets. Despite this glaring lack, IRAD, through its technological packages, allows farmers to move from subsistence farming to commercial or even small-scale industrial farming. Throughout this study; the objective aimed by the technicians and the researchers was to know how to produce and preserve the improved seeds, how to 
practice modern agriculture, the transformation of cultivated products into derived products, the marketing of agricultural products generating significant income.

A set of techniques and technologies which, according to IRAD officials, correct traditional retrograde practices and allow farming to become a real business, to limit massive imports of certain products (cassava) and the flight of currency.

To do this, IRAD is illustrated in the communication and training of producers through a number of activities, namely: training of producers and exhibition, processing and marketing of products from the harvest.

The West represents a potential production area of the country, this study allows the institute, secular arm of the State in agricultural research, to impregnate the producers on the revival of the culture of the cassava in Cameroon.

\section{REFERENCES}

1. Jean-Herve F. Networks local communication, social norms and technical change in agriculture -
The question forage the country 1'emmental Case 6tude in three towns to high-Saone thesis doctorate in sociology from 1 ' University of Paris X -Nanterre, 1990.

2. Lacombe P. Local agricultural development Stories and perspectives in Cahiers du GERDAL, 1987;11:89-99.

3. Faye F.The Diffusion of Scientific Knowledge in Agriculture, social meanings and transmission of knowledge, DEA in Social Sciences applied to development, Université francois Rabelais, Tours; 1984.

4. Anne-Charlotte D. Fodder-best: a gait of engineering collective advice projects breeders, Paris, LATI, 1990.

5. Boullier D. On the proper use of a critique of the diffusionist model: Discussion- pretext of the concepts of Everett M. Rogers in Reseaux, 1989;36:31-51.

\section{Websites Consulted}

www.irad.fr Producer development

www.irad.fr Cassava cultivation

www.google.fr Search engine

www.minresi.cm creation of research institutes. 